\title{
Environmental Management, from Theory to Practice
}

\author{
Azade Sadghi \\ Department of Management, West Tehran Branch, Islamic Azad University, Tehran, Iran
}

\begin{abstract}
Environmental management is a set of management processes and procedures that allow an organization to analyze, control and reduce the environmental impacts of its activities, products and services, and act more efficiently and controlling. The management of the environment tends to be "humane", in the sense that environmental issues should be considered after defining development objectives. In its easiest way, environmental management needs to do three major tasks: to identify targets, determine whether these goals are feasible or not? And formulating and implementing strategies for doing things that are feasible. Generally, the basic principles of environmental management include "providence and supervision", which are followed by comprehensive and far-sighted inventories and policies, the establishment of criteria and rules for evaluation and monitoring, coordination and implementation, and operations. The development of urban environmental management plans in the process of moving from policy to implementation requires "public participation". Local environmental projects with the participation of people can be adapted to the elements of the environmental management system and provide an appropriate model for the preparation and implementation of local environmental programs with the participation of people and legal entities.
\end{abstract}

Keywords: Environment, Supervision, Planning, Policy Making, Public Participation

DOI: $10.7176 /$ CER/11-5-06

Publication date:June $30^{\text {th }} 2019$

\section{Introduction}

According to the definition of UNESCO, the environment includes everything or almost everything; human beings, nature, and the relationship between the two. It affects all human activities and also affects them. In another conception with the above-mentioned conception of the concept of the environment in the same direction, the environment is defined as follows: everything that surrounds us, affects us and can affect us, forms the environment of ours. . It can also be understood that the environment consists of everything that surrounds the process of living, in itself collapsing and with which it is interacting. Management means the process of doing things efficiently and effectively by others. Environmental management is the decision-making process for regulating those human activities that affect the environment, so that the environment's sustainable capacity for human development is not impaired. An environmental management system is a set of management processes and procedures that allow an organization to analyze, control, and reduce the environmental impacts of its activities, products, and services, and more efficiently and effectively operate (Kubinova et al., 1998).

\section{The most important environmental issues of the world:}

The current environmental problems of the world can be summarized in the list of environmental hazards and threats (Makhdoom, 2005):

1. Depletion of the ozone layer

2. Greenhouse effect

3. Deforestation

4. Desertification

5. Increased population

6. Increased contamination

7. Reduce natural resources

8. Increased seawater level

9. Increase mental illness and increase crime

10. Excessive dependence on machine and machine

11. Outbreaks of unknown diseases such as AIDS

12. Risk of genetic manipulation

13. Acidification of fresh water and fertile soil

14. Salty soils

15. Gourmet Water

16. Increased waste and water after

17. Destroying and threatening plant and animal species

18. Reduction of fresh water resources and its loss

19. Overweight and excessive fishing

20. Destruction of plantations due to soil erosion 
21. Destruction of genetic resources

22. Increased use of pesticides and herbicides

23. Increasing wars and global hunger

\section{Definition of environmental management and its application scope:}

Environmental management is the decision-making process for regulating those human activities that affect the environment, in such a way that the enduring capacity of the environment is not impaired for human development (Barrow 1380). The management of the environment tends to be "humane", in the sense that environmental issues should be considered after defining development objectives. A common goal emphasized in the definitions of development is sustainability. Sustainability has a simple concept: living together among natural resources. The famous and useful quotation of sustainable development is presented in the Brentland Report of the World Commission on Environment and Development: Development that is capable of meeting today's needs without losing the ability to meet future generation needs is sustainable. This definition also represents the ideal purpose of environmental management (Chap man, 1384). More clearly, there is an optimal balance between natural resources consumption and this is the responsibility of environmental management that identifies this balance and uses its own skills - in planning and decision-making - to achieve it. Usually such a concept is adopted by environmental managers. In its simplest form, environmental management should do three major tasks:

1. Target detection

2. Determine whether these goals are feasible or not?

3. Developing and implementing strategies for doing things that are feasible.

\section{Fundamental Principles of Environmental Management:}

Generally, the basic principles of environmental management are "prospective and supervised", which are pursued through (Parhizkar, 1996):

- Critical and far-reaching programming and coding (mainly devoted to different programmers).

- Establishing criteria and rules for evaluation and monitoring.

- Creating coordination (environmental manager should adopt an interdisciplinary and multidisciplinary approach with an overall view)

- Execution and Operation: Despite sustainable development as a goal, it is related to foresight and supervision and also to the welfare of the human species, but it cannot be achieved under certain conditions, protective objectives or human well-being in the long run (Kṛiṣhna, 1385). Since the mid-1980s, new branches have emerged in the evolutionary process of environmental management:

- Environmental rules

- Assessing the effects and risks

- Comprehensive Quality Management (TOM) (leading to the emergence of comprehensive environmental quality management)

- Environmental aspects

- Environmental management systems

\section{Different approaches to environmental management:}

Environmental management has not evolved in isolation, and different planners have different views and attitudes toward environmental issues. Regional planners often adopt an ecosystem perspective and other planners with an ecosystem attitude. For example, McHarge's attention was drawn to the catchment areas of the river in 1969, or in 1977, Doukciadis tried to a scientific program can establish a balance with nature. Types of challenges, as well as the breadth of topics in sustainable development, confirm the fact that there are a variety of factors involved on the earth (for example, people, economic affairs, charity). That is, environmental managers may focus more on an ecosystem area in terms of economic activities or the exploitation of natural resources. Also, environmental managers may be more or less "human" or "canopy-driven", tech-sponsored or too green. For this reason, environmental management is followed by a variety of approaches (Barrow, 1380):

1. Case approach: This approach is developed in response to a particular situation.

2. Problem-Solving Approach: From a series of absolute measures, they adhere to the problem, problem, needs and solution.

3. Ecosystem Approach: Includes natural ecosystems (mountains, poses and heights, meadows, deserts, islands, lakes, etc.) and abnormal ecosystems (crops).

4. Regional Approach: This approach mainly includes ecological zones or bio-geophysical units that can sometimes have international aspects. That is to say, there are several areas that are common to several countries. For example, common areas between some countries or in general:

- Distribution areas 
- River catchment area

- Coastal zones

- The islands

- Areas covered by water development plans

- Executing areas for development projects

- Sea (such as the Mediterranean Sea, Baltic, North, etc.)

5. Specialized approach approaches: often adopted by specialists such as:

- Air Quality Management

- Water Quality Management

- Quality management of soil

- Environmental Health Management

- Urban management

- Managing seas and oceans

- Management with human ecological perspective

- Tourism Management and Ecotourism

- Managed protected areas

\section{Concept of Environmental Management System:}

An environmental management system is a way to legitimize environmental protection measures through corporate or institutional structures. An Environmental Management System is a set of management processes and procedures that allow an organization to analyze, control and reduce the environmental impact of its activities, products and services, and operate more efficiently and effectively. Expected benefits from the EMS include promoting environmental measures in all areas (including areas that have not yet been interfered), increasing the environment for reducing environmental pollution, increasing organizations' commitment to environmental protection, and performance and enforcement controls. More on interventions in the environment. EMS is theoretically a tool for problem identification and problem solving, which is based on the concept of continual improvement. This tool can be implemented in a variety of ways depending on the type of activity and its needs for environmental management in each organization. In particular, EMS standards have been developed by the International Organization for Standardization (ISO) and the European Commission (ECO) and Management and audit scheme (EMAS) (UNEP, 2001; Environmental Protection Agency, 2003).

An environmental management system consists of four main stages:

1. Plan

2. Do

3. Check

4. Act

These four steps in each environmental management project are carried out through a complete implementation cycle. The cycle and components of each stage are depicted in Figure 1 (UNEP, 2001). 


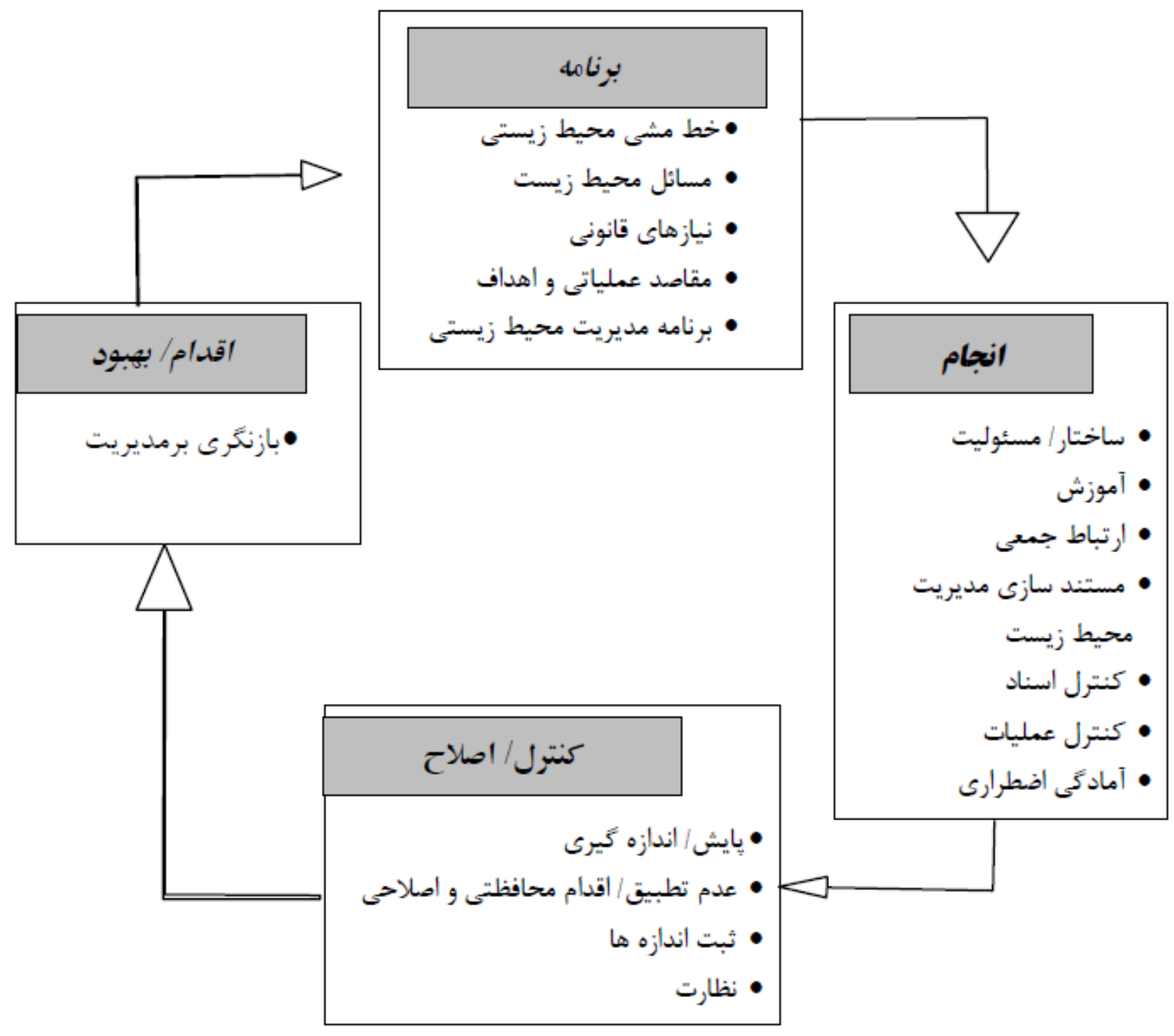

Figure 1 - Environmental Management System (UNEP, 2001).

The cycle introduced in an environmental management system will normally include the following five elements (Environmental Protection Agency, 2003):

1. Policy

2. Planning

3. Implement and Operation

4. Checking and Corrective Action

5. Management review

Requirements (elements) of the environmental management system (in the standard of ISO 14001):

- Environmental policy:

The standard states that an organization must define its environmental policy and seek senior management commitment. ISO 14001 describes a number of requirements for such a policy. The most important of these are (Taheri, 2000):

1. Implement existing environmental laws

2. Preventing the pollution of the environment

3. EMS Continuous Improvement

\section{- Planning}

This element represents the next step of the EMS, which is the same as planning, and divides it into four activities:

1. Identify the environmental aspects of the activities, products and services of an organization that can control and influence the major environmental impacts (in the form of an EIA).

2. Identify and maintain existing laws and other requirements that apply in environmental aspects to the activities of an organization's products and services. 
3. Setting goals and objectives

4. Establish EMS Environmental Management System

- Implementation and operation

This element is dedicated to the processes of establishing an EMS Environment Management System and is divided into seven parts:

1. Structure and responsibilities: As stated in the organization's and management's definitions, it is necessary to determine in each organization implementing the system of environmental management, the type of tasks, the persons selected for them and how they are performed.

\section{Knowledge and competence training:}

Requirements 14001 ISI: Our organization will define training needs, because all people with an environmental impact need to receive appropriate training. For this purpose, the training procedures should be determined and carried out.

EMS Essentials: EMS should be designed, implemented and maintained to ensure that everyone at all levels is aware of the following:

- The importance of complying with the policy and objectives of the environment and in keeping with the requirements specified and applicable in the management system.

- Potential environmental impacts caused by their activities and their work and the environmental benefits of the implementation

- Their role and responsibility in meeting policy and environmental goals and in keeping with the requirements of the management system.

- Potential outcomes of agreed execution procedures.

3. Mass communication:

4. Documentation of the Environmental Management System

5. Control of documents

6. Operation control

7. Preparedness and response in urgent situations

Urban Environmental Management System:

Today, with the disclosure of the important role of each individual in society and the importance of urban structures in improving the quality of the local environment, on the one hand, and the need for different types of environmental programs at different global, regional, national and local levels (including the city and the countryside) The importance of the preparation and implementation of local environmental programs has also become more prominent (Khanlari, 2009). Accordingly, sustainable development goals must be pursued through micro or local planning. For this reason, "All cities, especially cities with severe problems in terms of sustainable development, should develop programs in accordance with national laws, regulations and regulations aimed at addressing these issues and develop them to The path to your path "(Agenda 1377).

In this way, one of the areas of sustainable development will be the planning for local development, in the sense that we need to plan for an environmentally desirable local level, and if planning is carried out at this local level, in this case we can make a difference in our environment (Stocks Bridge Local Agenda 21, 1998). With this in mind, local governments are called to develop sustainable sustainability plans to pursue global goals through local planning in cities. This requires the formulation of implementation tools and implementation of programs (United Nations, 1992). One of these tools is the development of environmental management systems for cities, regions and urban neighborhoods. On the other hand, the realization of such programs and their desirability will not be possible except in the form of effective participation of a set of inhabitants including "authorities" and "local community" in its elaboration and implementation. Because many urban environmental problems and solutions are rooted in local activities and the participation and cooperation of people and local authorities is a determining factor in its sustainability (Agenda 21, 1377). The development of urban environmental management plans in the process of moving from policy to implementation requires the participation of "public participation" because even one person's participation in the community can also have an impact (Maldonado 2000, Layzer 2002, Carmin, 2003). Research shows that community-based environmental projects can be tailored to the elements of the environmental management system and provide a good model for the preparation and implementation of local environmental programs with the participation of people and legal entities (Faryadi, 2005).

International conventions and internal environmental laws:

In this section, the list will be referred to some international conventions and international environmental laws (Beberan, 2003):

- Declaration of the United Nations Conference on the Human and Environmental of Stockholm, 1972

- Rio de Janeiro Conference and Agenda 211992 
- Kyoto Protocol 1997

- Agreements on water pollution

1. The Treaty on the Prevention of Pollution from Ships through the Prohibition of the Disposal and Destruction of Stones and Other Wastes of Industrial and Industrial Pollution, known as the London Treaty of December 29, 1972

2. The International Atomic Energy Organization (IMO) World Water Convention to Prevent Pollution from Offshore Waters by 1973

3. Montreal directive for marine environmental protection against drought-related pollution in 1985

4. Global Compact Preparedness to deal with catastrophic events of oil pollution and cooperation and collective reaction against it 1990

- Agreements on air pollution:

1. The Air Pollution Convention at the regional level and at distances from the official borders of the polluters in 1979

2. The Vienna Convention for the Protection of the Ozone Layer in 1985

- Agreements on the health and safety of chemicals:

1. ILO Convention on the Prevention, Control and Mitigation of Workplace Dangers Caused by Air, Sound and Vibration Pollution in 1977

2. The FAO International Code of Practice and Measurement on the Distribution and Use of Pesticides at the 23rd FAO Conference in 1985

3. The United Nations Environment Program (UNEP) guidelines for the exchange of information on the adverse effects of chemical exchange and trade in the world (as drafted by the London Conference) by the United Nations Environment Program decision-making body in the year 1987 was approved.

4. Workplace Risk Prevention Convention Concerning the Reduction of Dangers of Chemical Use in the Workplace in 1990

5. Rotterdam Treaty on the trading of toxic and hazardous chemicals in 1981

- World Summit on Sustainable Development - Johannesburg 2002

\section{Internal environmental rules:}

Environmental laws are statutory laws that emphasize the protection of the environment, the prevention of pollution and even the improvement of the environment. The environmental laws of Iran are (Environment Organization, 2010):

1. The fifth article of the Constitution

2. Law on environmental protection and improvement

3. The law of hunting and fishing

4. The Law on the Prevention of Air Pollution

5. Law on the authorization of taxidermy of animals

6. The law allowing the receipt of fees for laboratory services

7. The Entry Law of Parks and Museums

8. Waste Management Law

9. The Law of the Fourth Program of Economic, Social and Cultural Development

10 Law of the Third Plan of Economic, Social and Cultural Development

11. The Second Program of Economic, Social and Cultural Development

12. The Islamic Penal Code - Sanctions

13. The Law on the Establishment of the Ministry of Agricultural Jihad

14. The law of reorganization and the assignment of tasks of organizations

15. Law on protection and exploitation of forests and pastures with amendments

16. Law on Protection and Protection of Natural Resources

17. The Dispute Settlement Law of the Forest and Rangeland

18. The Law of Conservation of Agricultural Land and Gardens

19. The Plant Protection Act

20. Bill of the Law on the Acquisition of Land and Real Estate for the Implementation of Public and Developmental Programs of the State

21. Legislative Bill on the Conservation and Development of Green Spaces in Cities

22. Law on protection and exploitation of aquatic resources of the Islamic Republic of Iran

23. Law of the Islamic Republic of Iran's Gulf and Sea

24. Law on the illegal fishing of the Caspian Sea and the Persian Gulf

25. Law on the Protection of the Sea and the River Borders of Contaminated with Petroleum

26. Land and Coastal Laws

27. The Law on the Conservation and Stabilization of the Edge and the Border of the River Borders 
28. Article 45 of the Law on the Recovery of Some Income of the Government and its Consumption in Certain Terms

29. The Law on the Regulation of Part Three of the Regulations for the Facilitation of Industrial Modernization and the Revision of Article 113 of the Third Plan Act

30. The law regulating part of the financial regulation of the state

31. The Law on Amendments to Articles of the Third Plan Act

32. Direct Tax Code

33. State Budget Act of 1383 of the whole country

34. Law on how to calculate and collect vehicle customs duties

35. Legal Bill Abolishing the Limit of Establishment of Factory and Industries within $50 \mathrm{Km}$ radius of Isfahan

36. Note 30 of the Budget Law 1328 of the whole country

37. The Law on the Establishment of the Company for the Collection and Sale of Property and its Articles of Association

38. Law establishing the Cultural Heritage and Tourism Organization

39. Law establishing the Natural Disaster Reduction Committee

40. Law on the amendment of the Road Safety and Railway Safety Act

41. Law on Industry and Mines and the Ministry of Industries and Mines

42. Mining Act

43. Amendment of Article 2, Article 1 of the Law on the Organization and Duties of the Ministry of Health and Medical Education

44. Oil law

45. Municipal Law

46. Law on the use of weapons by officers of the armed forces in cases of necessity

47. Law allowing the licensing of weapons by gendarmerie

48. Law on aggravating punishment of weapons smugglers and armed smugglers

49. Fair Water Distribution Law

50. Law on the Establishment of Water and Wastewater Companies

51. Law on the Establishment of Rural Water and Sewage Companies

52. Radiation protection law

53. Law of the Atomic Energy Organization of Iran

54. Law establishing the Supreme Council of Oceanography

55. Law establishing the Supreme Council of Urban and Architecture of Iran

56. Act establishing the High Council for the Coordination of Traffic in the Cities of the Country

57. Labor law

58. The Law on the Development of Tourism and Tourism, and the Modification of Articles 2 and 7

59. Law on Amendments to the Standards and Industrial Research Institute's Rules and Regulations

60. The law permits one of the deputies of the ministers and heads of independent organizations in the councils composed of several ministers

61. Statutes of the National Iranian Water Treasury

62. Law on the conservation and stabilization of the boundaries of the rivers and rivers

\section{Environmental Management Programs:}

1. Caring and monitoring: One of the most important principles in an Environmental Impact Assessment is to provide environmental monitoring and monitoring programs. The purpose of this program is to obtain information that measures the effects and consequences of the activities of a project or project, and the results of it are indicative of or not being accepted or unacceptable. The findings provide appropriate information and policies for controlling and implementing corrective actions and mitigating adverse effects. In the event of noncompliance, the necessary and necessary measures will be applied to laws, regulations, standards and standards, and ultimately to monitoring and monitoring programs (Monavari, 1380).

\section{- Concept of Environmental Impact Assessment:}

Environmental assessment is a systematic approach designed to generate, identify and compile information for assessing the effects of projects on the environment (Saleh and Pour Asghar, 2005). Environmental Impact Assessment is a formal process that has the potential consequences and outcomes examine a proposed project or project to anticipate with a view to mitigating the adverse impacts of the environment (Monavari, 1380) and other expressions on the development impact assessment of the effects of project activities on the environment. Development is a systematic process in which to predict and evaluate the potential impacts of a project on the environment, it deals with different options and it tries to choose the best option in terms of economic and ecological considerations. Environmental assessment is a method for identifying the potential impacts of development on the environment, a forecast for preventing environmental consequences by providing Better 
options (in terms of Ecological, social, aesthetic ...) is the result of those changes. An assessment of the effects of development can be defined as measuring changes in the event of turbulence. The process and the process of review and formal studies to evaluate past plans or predict the effects of the activities and functions of a project, plan, program, environmental policy, human health and social welfare, or, in other words, systematically identify or assess the impacts and effects of projects, Plans and plans are based on the physical, chemical, biological, cultural and socio-economic components of the environment (Makhdoum, 1369). The place to assess the effects of development in environmental studies is after planning for the use of land. Ideally, an assessment of the effects of development should be made before the project is implemented, but in some cases, in countries such as Iran, which has recently come to the legal review of the effects of developmental impact assessments, on completed and ongoing projects Exploitation is also used to reduce their destructive effects on the environment (Makhdoum, 1369).

2. Training: Providing environmental education programs in assessment reports plays an important role in reducing and controlling the environmental degradation and pollution factors of the project and projects. The first step in this area is to determine the responsibility for environmental management at the site of the project or project. The collection of basic information, the formulation of management strategies, the follow-up of operational issues and their control and review, the organization of training courses and workshops for employees and practitioners, and the optimization of the environmental information system from the training programs that should be included in the report.

3. Public Participation: The use of comments and views from local communities and stakeholders and influenced by the project of public organizations, NGOs and university specialists in the region is essential for an effective evaluation report. In other words, public participation is an important part of the environmental assessment, which is used in different stages of reporting the results. It is imperative to provide documentation for public opinion polls in the evaluation report to make them aware of their views. The use of public views and views through various scientific methods is achievable through the following:

- Responsible Participation of Local Communities Place of Implementation of the Project or its Area in the Review of the Report

- Informing and informing local communities and citizens about the implementation of the project or project

- Timely reporting of operations and actions to the public and authorities through the media

- Acquire opinions from local communities, government and non-governmental organizations, academic centers, etc. to improve activities and reduce potential adverse effects.

- Formation of planning committees in the region with the participation of the people or their representatives

\section{Conclusion}

The environment takes everything, or almost everything, according to the definition of the UNESCO organization; both human beings, both nature and the relationship between the two. It affects all human activities and is also affected by them. "In terms of its functional characteristics, the environment is divided into three categories: natural environment, socio-economic environment, and human-made environment. The management environment in the environmental field is better understood by management theories. Four main theory theories of systems, cybernetics, disorder theory and contingency theory can be mentioned from the main and effective management theories in guiding environmental management. Environmental management is the decision-making process for regulating those human activities that have an impact on the environment, in such a way that the enduring capacity of the environment is not impaired for the development of human life. The objective of environmental management is to promote and promote the concept of sustainable development. But achieving sustainable development requires appropriate management tools. The environmental management system is one of these tools. An environmental management system is a way to legitimize measures to protect the environment through corporate or institutional structures. An environmental management system is a set of management processes and procedures that allow an organization to analyze, control and reduce the environmental impact of its activities, products, and services, and operate more efficiently and effectively. EMS is theoretically a tool for problem identification and problem solving, which is based on the concept of continuous improvement. This tool can be implemented in different ways depending on the type of activity and its needs for environmental management in each organization. An environmental management system consists of four main stages of the program, implementation, control, operation, or action that their relationship with each environmental management project takes place through a complete implementation cycle. The requirements for an environmental management system in an organization are defined by the ISO 14001 standard. The use of ISO 14001 is exactly the same process that must be implemented in any environmental management project. In other words, ISO 14001 is an appropriate tool for conducting environmental management projects. The environmental management system in accordance with these standards has five parts: 1) environmental policy, 2) planning, 3) implementation and operations, 4) control and corrective action, and 5) management review. These five parts are referred to in the term standard clauses or elements and each sub section with standard implicit requirements. 
The fourth element is fundamental and the key to this standard is to set up and maintain an environmental management system for standard requirements. This element involves measuring and monitoring the impact of the organization's actions on the environment, taking action to prevent the continuation of the work and fixing it, registering test cases, and the results of inspections and reviews and audits of the environmental management system. That is, whether the environmental management activities are compatible with the environmental program and have the performances performed to control the effects? Given the global and sustainable goal of sustainable environmental management, local governments are called upon to develop sustainable sustainability plans to pursue global goals through local planning in cities. This requires the development of implementation tools and feasibility programs, one of these tools is the development of environmental management systems for cities, regions and urban neighborhoods. On the other hand, the formulation of urban environmental management plans in the process of moving from policy to implementation requires "public participation." Local community projects can be adapted to the elements of the environmental management system and provide a good model for the preparation and implementation of programs. Provides local environmental expertise with the participation of people and legal entities.

\section{References}

1. Beberan, Sedigheh, 2003, Document of the World Summit on Sustainable Development, Johannesburg, 2002 , National Committee on Sustainable Development - EPA.

2. Jay Barrow, Christopher, 1380, Principles and Methods of Environmental Management, Translated by Mehrdad Andrudi, Congressional Publishing House, Tehran.

3. Chap man, David. Creation of localities and places in the human environment. Translation of Shahrzad Faryadi and Manouchehr Tabibian. 1386 Q2, Tehran University Press.

4. Khanlari, Zahra. 1388 Elaboration of Environmental Management Program for Urban Sites in Thirteenth Nebn District 20th District of Tehran. Master's Thesis. University of Tehran.

5. Environmental Organization Site, 2010 www.irandoe.org

6. Saleh, Alireza and Poor Asghar Sangachin, Farzam, 2005, Economic Analysis of Environmental Consequences, Publications of Management and Planning Organization of Iran.

7. Taheri, Shahnam, 2000, Total Quality Management and ISO 9000 Series and ISO 14000 series specialties in Management and Industrial Engineers, New Science Publications, Lighting Design.

8. Kṛișhṇa, Payninaty, Sustainable Development of Economics and Mechanisms, 2006, Translation Ahmad Reza Yavari, University of Tehran.

9. United Nations Conference on Environment and Development, Agenda 1377, 21, translation by Dr Hamid Tarroudi and Seyed Amir Este, Environmental Protection Agency, with the assistance of the United Nations Development Program.

10. Makhdoum, Majid. 1369 Environmental Impact Assessment, Master Plan (First Stage), National Pars Agriculture, Industry \& Animal Company, Iran General Consulting Engineers, Report No. 27.

11. Makhdoom, Majid, 2005, Sholdouh Amayesh Land, Institute of Publications and Printing of Tehran University.

12. Monavari, Masoud, 1380, Environmental Impact Assessment Guide, Environmental Protection Agency.

13. Carmin j, 2003, "Local Action in a Transitional State: Community Responses to Proposed Development in the Czech Republic", 1992-1996, Social Science Quarterly, Austin: Mar 2003, Vol, 84, Iss, 1; pg, 191, 19pgs.

14. Environmental Protection Agency, 2003, "Environmental Management Systems", U.S.A.

15. Faryadi, Shahrzad ,2005, “A Methodology for Participatory Local Environmental Planning”, Journal of Environmental Studies, University of Tehran, Tehran, Iran, April 2005, Iss,37; p,14.

16. Kubinova, Suzana and Santora, Zdenik. 1998. The Eco- Management and Audit Scheme (EMAS) in small an medium -sized enterprises, A guide for companies management.The ministry of the environment. www.ceu.cz/eng/emas/smsized.htm

17. Layzer Judith A, 2002, "Citizen Participation and Government Choice in Local Environmental Controversies”, Policy Studies Journal, Urbana: 2002, Vol, 30, Iss, 2; pg, 193, 15 pgs.

18. Maldonado Robert Weech and Merrill Sonya B., 2000, "Building Partnership with the community: Lessons from the Camden Health Improvement Learning Collaborative", Journal of Healthcare Management, Chicago: May/Jun.2000, Vol, 45, Iss, 3; pg, 189, 17pgs.

19. Stocks Bridge Local Agenda 21, 1998, Local Agenda 21, www. Stocksbridge.demon.co. u.k.

20. UNEP, Sustainable Agri-food Production and Consumption Forum, 2001, "Environment Management System". www.agrifoodforum. net/practices/ems.asp.

21. United Nations, 1992, Agenda 21Chapter 7, "Promoting Sustainable Human Settlement Development", RiodeJaneiro. 